\title{
Culture and Ecotourism Management of Dams in North-eastern Thailand
}

\author{
Orathai Sinthusiri ${ }^{1}$, Boonsom Yodmalee ${ }^{1} \&$ Sastra Laoakka $^{1}$ \\ 1 The Faculty of Cultural Science, Mahasarakham University, Khamriang Sub-District, Kantarawichai District, \\ Maha Sarakham Province, Thailand \\ Correspondence: Orathai Sinthusiri, The Faculty of Cultural Science, Mahasarakham University, Khamriang \\ Sub-District, Kantarawichai District, Maha Sarakham Province 44150, Thailand. E-mail: \\ osinthusiri132@gmail.com
}

Received: April 29, 2014 Accepted: June 6, 2014 Online Published: June 26, 2014

doi:10.5539/ach.v6n2p205 URL: http://dx.doi.org/10.5539/ach.v6n2p205

\begin{abstract}
This qualitative research examines the culture and ecotourism management of three North-eastern Thai dams. Using methods of survey, observation and interview, the research team identifies ten areas of ecotourism management in the area: food, location, administration, transportation, souvenirs, surrounding environment, waste disposal, customs, sports and safety. Although efforts are being made to manage waste and tourist activities, the research finds that five principal problems remain with management of the surrounding environment: deforestation, litter, construction, traffic, and water contamination. Additionally, there are problems with inadequate tourist facilities and insufficient staffing during the high festival seasons. To address the five problems with the park areas, there are five individual solutions: reforestation, stronger waste disposal management, more control of building, regulation of noise and emissions from vehicles and monitoring of dam water quality.
\end{abstract}

Keywords: dam, management, Isan, ecotourism, Thailand

\section{Introduction}

The Tourism Authority of Thailand revealed that Thailand was the most visited ASEAN country in 2008. Income generated from foreign tourism for the Thai economy was valued at 574,521 million baht. In 2009, income increased to $715,985.18$ million baht and comprised $7.91 \%$ of the total Thai economy. This value was generated from 14,149,180 tourists. At the time of this investigation, it was estimated that the 2013 figure for foreign tourists entering Thailand would reach 20 million (Department of Tourism, 2013). Factors increasing Thailand's popularity among foreign tourists are both internal and external.

Internally, Thailand has a rich natural and cultural heritage to showcase, which is both original and accessible. Externally, global communications are improving and connecting the Indochinese Peninsular with even more countries, while the global economic crisis is making cheap Thai prices very attractive. This is reflected in the Eleventh National Economic and Social Development Plan (Office of the National Economic and Social Development Board, 2011), which emphasizes using self-sufficient economic policy as a method for developing the country.

The plan places particular importance on the sustainable employment of local knowledge and the surrounding environment to promote tourism. Given the importance of tourism to the Thai economy and the introduction of government policies to support the industry, there has also been greater emphasis placed on public involvement and community participation in managing local tourism, especially ecotourism.

The Thai authorities and private sector have been made aware of the attraction of Thai culture, environment and nature to foreign tourists by the results of surveys, such as those conducted by Travel and Leisure Magazine, which named Bangkok as 'The World's Best City' for four consecutive years from 2003 to 2006 (Daily News, 2013). Accordingly, government institutions and private businesses have shifted management focus of tourist attractions to the surrounding environmental resources in order to meet the recommendations of the development plan and satisfy tourist demand (Chachakoon, 2011). 
One such example is the management of Thai dams. There are 33 large dams, 367 medium-sized reservoirs and 4000 small reservoirs to be found across Thailand (Electricity Generating Authority of Thailand, 2010). The North-eastern region of the country, colloquially known as Isan is particularly suitable for agriculture and the principal occupation of Isan residents is farming, an occupation that by nature requires water. In order to assist with irrigation, dams were constructed throughout the region. The collection of water at dams and reservoirs has caused the natural environment in the surrounding area to flourish. This abundance of nature has led to the emergence of new tourist attractions, which generate income for the local economy through the provision of hotels, restaurants, car parking, souvenir shops, toilet facilities and local land and water transport. The large dams in this region fall under the jurisdiction of the Ministry of Energy and include Ubol Ratana Dam in Khon Kaen Province, the first multi-purpose dam in Thailand, Lampao Dam in Kalasin Province and Chulabhorn Dam in Chaiyaphum Province (Ministry of Tourism and Sports, 2010).

Ecotourism is one method of tourism employed by the Ministry of Energy and the Ministry of Agriculture and Cooperatives in dam areas. In response to this, Ubol Ratana, Lampao and Chulabhorn Dams have developed management to increase the variety of tourism on offer. Their efforts have seen many tourists visit the dams to learn about the local lifestyle and exchange knowledge about the environment, customs and culture. Ecotourism is also increasingly important for the livelihoods of the residents who once lived off the land and have been forced from the fertile dam area. The research team was thus interested in studying the management of ecotourism by the Ministry of Energy and the Ministry of Agriculture and Cooperations at dams in Isan to identify areas for improvement that will benefit the surrounding communities. The primary purpose of this study is to provide a resource for local dam management committees in Thailand.

\section{Literature Review}

There has been limited domestic research into the state of ecotourism at dams in North-eastern Thailand. Darchanee Empan (2001) conducted a study on the satisfaction and behaviour of tourists visiting Ubol Ratana Dam. The favourite tourist activities among Empan's sample were boat trips on the reservoir, photography at the viewpoints and relaxation in the public parks. Empan's research discovered that tourists wanted more places to stay at the dam site and wished for a cleaner environment. Ecotourism in Thailand has been found to encourage people in the community to develop and care for their natural resources (Wongduy, 2003) because it causes society to change by boosting the local economy (Brajong, 2003; Jamrunsiri, 2003). Ploenpit Kreubun (2002) argued that, for ecotourism to succeed in Thailand, the locals must first be educated in the importance of their natural resources because it is the surrounding environment that attracts tourists (Jantawee, 2005; Kanjanakit, 2001). Ease of access, education resources, activities on offer and ambience are also credited with attracting tourists to ecotourism sites in Thailand (Yuyendee, 2003).

For the most part, domestic research about tourism in Thailand has been concerned with the management of natural, cultural and ecological attractions (Chaitorn, 2009). A number of problems have been identified with tourist attractions in Thailand, including poor distribution of environmental information, lack of systematic budget allocation, insufficient amenities, lack of refreshment variety, poor community coordination and pollution (Bunbanyarot, 2002; Jaemulidrat, 1999; Nantee, 2001; Pipattanayotapong, 2004). Although Worapak Leusittisak (2004) found noise pollution at Thai ecotourism attractions to be little more than a nuisance, litter, inadequate waste disposal and lack of control on tourist activities in Thailand have the biggest impact on the surrounding environment (Banjakan, 2006; Battadecha, 2007).

The focus of a number of studies has been the management of ecotourism sites and finding the best way for conservation and incorporation of traditional knowledge. Chaisit Damrongwajaroen (2007) identified community participation and guide training as essential for conservation, while Pusawat Sukliang (2002) recognized the inheritance of a local identity as vital to fostering the necessary strength of feeling required for adequate community involvement (Brabpiree, 2000). Witchuda Hijaroen (2003) categorized the problems at ecotourism sites in Thailand as being caused by internal management and external community involvement. Hijaroen suggested a four-step process of planning, preparation, implementation and maintenance to combat these issues. Solutions include control of tourist numbers, development of site facilities and enforcement of conservation regulations (Jitruangnan, 2003; Srisuwan, 2009; Yotbakorn, 2004).

On an international level, ecotourism in Thailand has been examined in more general terms (Larsen, Calgaro \& Thomalla, 2011; Laverack \& Thangphet, 2007; Laws, Richins, \& Agrusa, 2011) but there have not been any macro-level investigations on dams in Isan. Paul Owusu Boi (2004) highlighted similar problems of insufficient knowledge and information distribution in the national parks of Ghana, which have also been documented in studies across the globe (Buultjensa, Ratnayakeb, Gnanapalab, \& Aslamb, 2005; De Los Angeles 
Somarriba-Chang \& Gunnarsdotter, 2012; Lai \& Nepal, 2006). International research has also shown how funding is reflected in the quality of the tourist experience and resource maintenance (Botha, 1991). In the 1980s Ruth Ealine (1984) noted that tourists needed increased security presence and modernized facilities, while in the 1960s there was reluctance among tourists for their privileges restricted and numbers to be limited (Hendee et al., 1968). More recently it has been observed that the main objective of tourism for the tourist is an experience and a tourist environment must be developed to provide this (Swarbrooke, 2002). These studies show that the tourist experience has been the fundamental concern throughout the history of tourism and is a crucial factor when considering any park management, including the management of parks in North-eastern Thailand (Butler \& Boyd, 2000; Eagles \& McCool, 2002). However, this experience must not detract from the community lifestyle and, above all, must not harm the natural resources and surrounding environment. John Preissing (2006) identified success-factors for economic development plans in the community, one of which was the monitoring of natural resources. In analysis of ecotourism in Costa Rica, Caroline Stem (2002) went a step further by saying that ecotourism provides an economic choice for the community but, in order for that choice to be realized, local tourism industries must ecologically adapt to benefit the community. Michael Coltman (1989) developed a nine-point strategy for the success of cultural tourism, which is equally applicable to ecotourism in a broader sense. Coltman outlined his plan as follows: (1) the locals must be encouraged to recognize the potential benefit of tourism for the economy; (2) development must be decided upon by the community; (3) locals must agree with the marketing strategy; (4) there must be cooperation between the government and the private sector; (5) there must be no harmful effects on the local population; (6) budget and manpower must be provided by the area so that locals may control them; (7) there must be adequate opportunity for locals to participate; (8) activities, events and festivals should reveal the history, lifestyle and identity of the local people; (9) community problems must be solved first. Despite covering ecotourism events, the development of resources and effective planning and strategies, there is little international focus on the dams of North-eastern Thailand.

\section{Methodology}

This was a qualitative research conducted from May 2012 to May 2013. The principal aim of the research was to identify current conditions and problems with the management of ecotourism in dams under the jurisdiction of the Ministry of Energy and the Ministry of Agriculture and Cooperatives in Isan in order to identify areas for development to benefit the surrounding environment and communities. Dams were purposively selected to comprise the research area based on five criteria: they were located in the Isan region; they were under the jurisdiction of the Ministry of Energy and the Ministry of Agriculture and Cooperatives; they had prominent natural or cultural tourist attractions; they had attractive water, beaches and scenery and a good atmosphere; they had parkland, forest reserves and conservation areas. The three dams that met these criteria were Lampao Dam in Kalasin Province, Ubol Ratana Dam in Khon Kaen Province and Chulabhorn Dam in Chaiyaphum Province.

The research population was purposively selected and comprised of members of the local community surrounding the three dams, as well as local officials, tourists in the area and management personnel. The sample group totalled 120 individuals, divided into three groups. The groups were selected based on their level of authority within dam tourism management. Group one was composed of dam directors, local government leaders, representatives of the Ministry of Energy and the Ministry of Agriculture and Cooperatives and community heads, totalling 30 individuals. Group two was composed of local officials, and business personnel plying their trade in the immediate area, totalling 60 individuals. Group three was composed of tourists, academics and community traders, totalling 30 individuals.

This investigation applied both documentary study and field research in the collection of data. Research data was initially collected by basic qualitative survey relating to the research area, specifically ecotourism in Kalasin, Khon Kaen and Chaiyaphum Provinces (Jansen, 2010). Following this, the research team entered the field and studied the management of ecotourism in Isan by way of participant observation. The three processes of observation, inquiry and recording were employed. The research team also observed management at the dams in a non-participant capacity. The informants provided data by means of structured and non-structured interview. The structured interview was conducted in four parts. Part one gathered personal information about the respondent, part two asked for knowledge of the history of the dams and tourism management in the area, part three asked for opinions about current dam management and part four asked for suggestions how to improve the management and solve current problems. The results were then presented to the informants in a series of focus group discussions, where methods for improvement were concluded.

The data was continuously validated during and after the collection process by way of methodological triangulation in terms of time, place and data source according to the methods of Songkoon Chantachon (2006). Investigator triangulation was also used to assess any data collected by different people. Analytic induction was 
used to examine the data, along with typological analysis. Six typologies were chosen during the analysis period: acts, activities, meaning, relationship, participation and setting. The research results were then presented as a descriptive analysis.

\section{Results}

The management model employed by Lampao, Ubol Ratana and Chulabhorn Dams focuses on four service principles: man, material, money and management. Each principle is sub-divided into the ten key areas of management: food, location, administration, transportation, souvenirs, surrounding environment, waste disposal, customs, sports and safety. Investigation found that the communities surrounding each dam benefit from job opportunities and the ability to trade in and around the tourist area. As a result, the local communities are directly affected by the tourist business, the quality of which is primarily determined by efficient management and upkeep of the dams. The following is a description of the current state of each area of management and its accompanying problems based on results from participant observation and interviews with all three respondent groups.

\subsection{Food}

There are standard restaurants at each of the three dams in this study, which are Dok Ked Restaurant at Lampao Dam, Reuan-Pan-Kam Restaurant at Ubol Ratana Dam and Ruean-Nam-Prom Restaurant at Chulabhorn Dam. Each restaurant employs regular staff. However, the main weakness with staff is a lack of service culture. In the surrounding area there are also private Isan restaurants. The food served includes traditional Isan fare of sticky rice, papaya salad, baked fish and grilled chicken. This food is traditional, popular in the area and is sold at cheap prices. The food may also be bought and consumed at leisure in the shade of the surrounding trees. The largest problem at the restaurants was the inadequate provision of food and personnel during the high festival seasons, especially the Songkran Festival. The service at Ubol Ratana Dam was also found to be slow, due to lack of staff, and expensive. Additionally, the flavours of the food were of sub-standard quality. At Chulabhorn Dam, similar problems with insufficient personnel and slow service were encountered. There was also no local food on offer because tourists prefer to eat Central Thai cuisine.

\subsection{Location}

Lampao, Ubol Ratana and Chulabhorn Dams all provide facilities for tourists, including car-parking, restrooms, guesthouses, restaurants and sports venues (petong at Lampao Dam and golf at Ubol Ratana and Chulabhorn Dams). There are also meeting rooms for seminars. The dams provide space for camping and hold scout jamborees, which are booked through the information office. During the Songkran festival, there are not enough guesthouses to accommodate the visitors. During this high season, there are also not enough staff members.

\subsection{Administration}

The sites employ staff in clear roles, such as the guesthouse manager, who must handle and maintain the running of the guesthouses and be available to offer services to guests throughout the duration of their stay. Facilities are provided for the visitors' convenience, including parking areas, toilets, appliances in the guesthouses, meeting rooms and camp sites. There are also boat services available. Funds for the day-to-day management of the dams come from the sponsorship budget of the government ministries of energy and agriculture. These budgets are designed to develop the attractions in a suitable manner. Work is conducted systematically, according to the strategic plan of each dam.

\subsection{Transportation}

There are convenient routes to each of the three dams covered by this investigation. Tourists can access the dams by private car, tour bus or motorcycle. Tourists can access the sites when they wish and there are no customs or duties to be paid. The dams are also relatively easy to access by plane or train from Bangkok, requiring only a short car transfer from the nearest airports or train stations. This option is perhaps faster, yet more expensive. During the Songkran Festival there are traffic jams because there are not enough signs around the dam area to direct traffic. The local public transport fares are not standardized, which causes visitor experiences to differ.

\subsection{Souvenirs}

Souvenirs are part and parcel of the tourist experience and the most popular souvenirs among visitors to the dams are products made in the local communities. It is policy to encourage the local community members to create goods for sale in the attraction area to promote the local identity. Goods on offer at Lampao and Ubol Ratana Dams are predominantly fish-based, such as fish sausages and fish snacks. At Chulabhorn Dam, shirts and bags are more commonly sold as souvenirs. However, the souvenirs do not reflect the identity of the dam 
and the sale price is not standardized. The souvenirs at Ubol Ratana and Chulabhorn Dams were found to be expensive and the stalls did not provide quality assurance.

\subsection{Surrounding Environment}

The dams employ many methods of environmental management. One such example is reforestation, whereby new trees are planted to replace those destroyed with the construction of the dams. There is a program underway to manage this process on Pupankam Mountain at Ubol Ratana Dam. Additionally, there are programs to control waste disposal by introducing lidded waste bins, disposing of waste at sites far from the attractions and using correct disposal methods, such as separation of wet and dry waste for incineration or use of landfill sites. Each dam site recognizes the importance of effective waste disposal management and consistently implements appropriate techniques, so as not to unduly harm the surrounding environment. Nevertheless, these measures are only partially underway and five principal problems remain with management of the surrounding environment: deforestation, litter, building materials blocking the water, traffic causing noise and air pollution, and water contamination destroying the habitat of local wildlife.

\subsection{Waste Disposal}

The three dams operate different procedures for waste disposal. At Lampao Dam, Lampao Sub-district Municipality assists with the management of waste disposal by providing vehicles to transport the waste away from the dam. The costs for this service are covered by each restaurant, shop and guesthouse with a monthly fee of 150 Thai baht. The dams at Ubol Ratana and Chulabhorn each have their own waste disposal vehicles to take liquid waste to an off-site disposal area about two kilometres away from the dams. There are signs throughout the dam areas reminding visitors to dispose of waste in the bins provided and refrain from littering. The major problem is litter. Tourists do not use the litter bins provided and there is no discipline in maintaining park cleanliness. Additionally, the rubbish trucks do not collect trash every day, causing the wind to blow excess litter to all areas of the park; there is an especially large amount of rubbish during the Songkran Festival.

\subsection{Customs}

The dams conserve and promote the Isan culture and annual ceremonies. Important ceremonies held in the areas are Songkran Festival and the Pusing Temple Tak Bat Thewo Festival at Lampao Dam, the Rocket Festival at Ubol Ratana Dam and Songkran and New Year Festivals at Chulabhorn Dam. There are also religious ceremonies held in the dam areas, including merit-making and worship of monks. Moreover, activities are held related to the customs that have been inherited over time, which provide an opportunity for tourists to participate, learn and enjoy the traditions. At Lampao Dam, no problems were found with customs and ceremonies, although at Ubol Ratana and Chulabhorn Dams it was discovered that tourists did not ensure adequate safety of their possessions during ceremonial events.

\subsection{Sports}

There are sports facilities open every day for visitors, staff and managers of the dams. At Lampao Dam there are petong courts, while at Ubol Ratana and Chulabhorn Dams there are golf courses. There are costs for use of the facilities, which depend on the time of day. No problems were found with the petong courts at Lampao Dam. The golf courses at Ubol Ratana and Chulabhorn Dams are heavily staffed, which is not economical.

\subsection{Safety}

As personal and material safety are chief concerns of tourists, the dams have implemented measures to make the tourists secure in their visits. There are guards stationed at the gate day and night to protect the facilities, the people and the possessions within the dam area. There are also first aid officials on-site in the event of an emergency and signs around the dam area warning visitors against swimming, to watch out for forest elephants and about sharp turns on the roads. The biggest safety concerns are during the high season and festivals, when there are large numbers of visitors and high volumes of traffic. Extra care must be taken at these times when tourists are more liable to drink and drive.

The strengths and weaknesses discovered from survey, observation and interviews were discussed with informants in focus groups. From the discussions, a set of solutions was outlined to solve the problems with ecotourism management at dams in Isan. These solutions are summarized in table 1 (Table 1). 
Table 1. A summary of solutions to management problems in three ecotourism dams in North-eastern Thailand

\begin{tabular}{|c|c|c|c|}
\hline & Lampao Dam & Ubol Ratana Dam & Chulabhorn Dam \\
\hline Food & $\begin{array}{l}\text { Food should be used that } \\
\text { can be stored for a long } \\
\text { time, so to combat } \\
\text { shortages in times of high } \\
\text { customs. }\end{array}$ & $\begin{array}{l}\text { More staff should be } \\
\text { appointed to cope with } \\
\text { the heavy workload and } \\
\text { the quality of food should } \\
\text { be improved to reflect the } \\
\text { price. }\end{array}$ & $\begin{array}{l}\text { More staff should be } \\
\text { appointed to cope with the } \\
\text { heavy workload. }\end{array}$ \\
\hline Location & $\begin{array}{l}\text { The number of tourists } \\
\text { should be limited and this } \\
\text { should be achieved by } \\
\text { removing the ability to } \\
\text { book guesthouses by } \\
\text { telephone. }\end{array}$ & $\begin{array}{l}\text { Information leaflets } \\
\text { should be provided about } \\
\text { the location. }\end{array}$ & $\begin{array}{l}\text { Information leaflets } \\
\text { should be provided about } \\
\text { the location. Officers must } \\
\text { complete routine location } \\
\text { checks, with checks } \\
\text { lasting one hour at a time. }\end{array}$ \\
\hline Administration & $\begin{array}{l}\text { Programs should be } \\
\text { introduced to present the } \\
\text { dams to local organizations } \\
\text { to seek sponsorship. }\end{array}$ & $\begin{array}{l}\text { Income should be } \\
\text { generated from } \\
\text { recreational activities. }\end{array}$ & $\begin{array}{l}\text { Income should be } \\
\text { generated from } \\
\text { recreational activities. }\end{array}$ \\
\hline Transportation & $\begin{array}{l}\text { The roads should be } \\
\text { controlled better by } \\
\text { introducing speed limits. }\end{array}$ & $\begin{array}{l}\text { Traffic should be } \\
\text { managed using a one-way } \\
\text { system or making traffic } \\
\text { enter and exit the site at } \\
\text { different points. }\end{array}$ & $\begin{array}{l}\text { Traffic should be } \\
\text { managed using a one-way } \\
\text { system or making traffic } \\
\text { enter and exit the site at } \\
\text { different points. }\end{array}$ \\
\hline Souvenirs & $\begin{array}{l}\text { Support should be given to } \\
\text { sale of souvenirs that create } \\
\text { an identity for the dam } \\
\text { area. }\end{array}$ & $\begin{array}{l}\text { The quality of goods } \\
\text { should be developed to } \\
\text { reflect their sale price. }\end{array}$ & $\begin{array}{l}\text { The quality of goods } \\
\text { should be developed to } \\
\text { reflect their sale price. }\end{array}$ \\
\hline $\begin{array}{l}\text { Surrounding } \\
\text { Environment }\end{array}$ & \multicolumn{3}{|c|}{$\begin{array}{l}\text { To address the five problems with the park areas, there are five individual solutions: } \\
\text { 1. Reforestation should be done to replace the felled trees } \\
\text { 2. Lidded waste disposal bins should be introduced; waste should be disposed } \\
\text { daily; disposal sites should control pollution } \\
\text { 3. Building should be more strictly controlled } \\
\text { 4. Noise and emissions from vehicles must be controlled } \\
\text { 5. The quality of the dam water must be monitored and information provided to } \\
\text { tourists to help maintain the cleanliness of the water }\end{array}$} \\
\hline Waste Disposal & $\begin{array}{l}\text { Waste disposal vehicles } \\
\text { must collect waste daily; } \\
\text { there must be greater waste } \\
\text { disposal control and more } \\
\text { information provided for } \\
\text { tourists. }\end{array}$ & $\begin{array}{l}\text { Additional litter bins } \\
\text { must be provided during } \\
\text { festival times and waste } \\
\text { must be collected twice } \\
\text { daily, in the morning and } \\
\text { in the evening. }\end{array}$ & $\begin{array}{l}\text { Additional litter bins must } \\
\text { be provided during } \\
\text { festival times and waste } \\
\text { must be collected twice } \\
\text { daily, in the morning and } \\
\text { in the evening. }\end{array}$ \\
\hline Customs & N/A & $\begin{array}{l}\text { Information must be } \\
\text { provided to warn tourists } \\
\text { to be more careful with } \\
\text { their valuables }\end{array}$ & $\begin{array}{l}\text { Information must be } \\
\text { provided to warn tourists } \\
\text { to be more careful with } \\
\text { their valuables }\end{array}$ \\
\hline Sports & N/A & $\begin{array}{l}\text { Staff should be employed } \\
\text { on a monthly basis to } \\
\text { prevent problems of } \\
\text { resignation. }\end{array}$ & $\begin{array}{l}\text { Staff should be employed } \\
\text { on a monthly basis to } \\
\text { prevent problems of } \\
\text { resignation. }\end{array}$ \\
\hline Safety & $\begin{array}{l}\text { There must be more control } \\
\text { of roads and traffic }\end{array}$ & $\begin{array}{l}\text { There must be more } \\
\text { control of roads and } \\
\text { traffic }\end{array}$ & $\begin{array}{l}\text { There must be more } \\
\text { control of roads and } \\
\text { traffic }\end{array}$ \\
\hline
\end{tabular}




\section{Discussion}

The problems identified by this investigation are similar to those found by related domestic (Bunbanyarot, 2002; Jaemulidrat, 1999; Nantee, 2001; Pipattanayotapong, 2004) and international research (Boi, 2004; Stem, 2002). Throughout this study, the research team realised the importance of the guesthouse for the ecological tourist sites. Many visitors to the dams come to study nature or to observe the lifestyle of the local communities. They require a place to stay so that they may accurately complete these studies over a number of days. This is in agreement with both Boi (2004), who argued that ecotourism and knowledge are inseparable, and Brawet Wasee (2007), who concluded that lasting tourism depends on the ability of the tourist to relate to and understand the environment they are in. Guesthouses provide this opportunity. Restaurants are of equal importance in creating the tourism environment, as alluded to by Swarbrooke (2002). These must be managed with care and their cleanliness maintained, especially during Songkran Festival in April (Yotbakorn, 2004). Nedchanok Nantee (2001) also found the canteens and conveniences in general to be great attractors for tourists in studies of Lamphun Province. Moreover, the staff shortages in the restaurants during high season and lack of general information for tourists as found by this investigation correspond to the shortages identified by Taddaw Bunbanyarot (2002) in analysis of Phu Chi Fa national park.

In order to impress and satisfy visiting tourists, it is necessary for the dams to use four different methods of management. Firstly, the quality of local managers and staff must be developed so that they can efficiently and effectively meet visitor needs without sacrificing friendliness. Secondly, power must be given to staff to provide information to tourists and these staff must be rewarded by the organization if they are found to have had a positive effect on the dam and its visitors. Thirdly, a service culture must be created to promote service speed and politeness. Fourthly, service management must be uniform and all guests must be treated equally. These findings relate to the research of Michael Coltman (1989), who concluded that the meaning of tourism management is the mutual relationship between tourists, tourism managers, government tourism organizations and the local people in the tourism area. It is important for this relationship to be continually worked on so that visitors continue to be impressed. As such, the management of the different elements of the relationship is vital.

\section{Conclusion}

By analysing the management of ecotourism at the dams of Isan in ten categories, the potential of tourism in the area is made visible. In response to environmental problems, reforestation should be done to replace the felled trees, lidded waste disposal bins should be introduced, waste should be disposed daily, disposal sites should control pollution, building should be more strictly supervised, noise and emissions from vehicles must be controlled, the quality of the dam water must be monitored and information must be provided to tourists to help maintain the cleanliness of the water. To combat problems with the tourism environment, the quality of local managers and staff must be developed, power must be given to staff to provide information for tourists, a service culture must be created and service management must be uniform. For the potential of ecotourism in the dams of Isan to be realised, there must be local participation and the continued involvement of the Ministries of Energy and Agriculture and Cooperatives. Questions arose from this investigation and it would be valuable to ecotourism in Thailand if further research is conducted into the variety of ecotourism activities, conservation methods with community participation, health tourism and business tourism. In the meantime, this research is one of the first of its kind to be designed for use by management committees to improve ecotourism in the dams of North-eastern Thailand.

\section{References}

Banjakan, A. (2006). Ecotourism among hill-tribe communities: A case study of Pachang Noi Sub-district, Pong District, Payao Province [in Thai]. Chiang Mai: Chiang Mai University Press.

Battadecha, P. (2007). Home-stay tourism and ecotourism at Basaknam village, Luang Nuea Sub-district, Doi-saket District, Chiang Mai Province [in Thai]. Chiang Mai: Chiang Mai University Press.

Boi, P. O. (2004). Residents attitudes and perceptions toward national parks and ecotourism development in Ghana: the case of dome community in the Digna National Park. Dissertation Abstracts International, 42(6).

Botha, B. P. (1981). Park and recreation administration for municipalities of South Africa: A study of A Group municipal authorities. Dissertation Abstracts International, 42, 783-784.

Brabpiree, M. (2000). Community potential to manage tourist attractions: A case study of the Tai Song Dam community at Ban Kao Yoi, Kao Yoi Sub-district, Kao Yoi District, Petchaburi Province [in Thai]. Chiang Mai: Chiang Mai University Press. 
Brajong, K. (2003). The influence of tourism on the community: a case study of Sri Tan Village, Pukradeung District, Loei Province [in Thai]. Unpublished PhD thesis. Loei Rajabhat University, Loei.

Bunbanyarot, T. (2002). The management method for ecotourism at Phu-Chi-Fa national park [in Thai]. Chiang Mai: Chiang Mai University Press.

Butler, R. W., \& Boyd, S. W. (2000). Tourism and national parks: Issues and implications. Chichester: Wiley.

Buultjensa, J., Ratnayakeb, I., Gnanapalab, A. \& Aslamb, M. (2005). Tourism and its implications for management in Ruhuna National Park (Yala), Sri Lanka. Tourism Management, 26(5), 733-742. http://dx.doi.org/10.1016/j.tourman.2004.03.014

Chachakoon, N. (2011). The tourism industry [in Thai]. Bangkok: Chulalongkorn University Press.

Chaitorn, S. (2009). The development of a tourism model for cultural home-stays among the indigenous Laovien and Laosong [in Thai]. Unpublished PhD thesis. Mahasarakham University, Mahasarakham.

Chantachon, S. (2006). Cultural qualitative research [in Thai]. Kalasin: Prasan Printing.

Coltman, M. (1989). Tourism Marketing. New York, NY: Van Nostrand Reinhold.

Daily News. (2013). Bangkok named the World's Best City for the fourth consecutive year' [in Thai]. Daily News. Retrieved from www.dailynews.co.th/bkk/220199

Damrongwajaroen, C. (2007). Cultural tourism conservation management by community participation: a case study of Pupyon, Pupan District, Sakon Nakhon Province [in Thai]. (Unpublished $\mathrm{PhD}$ thesis). Mahasarakham University, Mahasaarakham.

De los Angeles Somarriba-Chang, M., \& Gunnarsdotter, Y. (2012). Local community participation in ecotourism and conservation issues in two nature reserves in Nicaragua. Journal of Sustainable Tourism, 20(8), 1025-1043. http://dx.doi.org/10.1080/09669582.2012.681786

Department of Tourism. (2013). Tourist arrivals in Thailand [database]. Retrieved from http://www.tourism.go.th/tourism/th/home/tourism.php?id=12

Eagles, P. F. J., \& McCool, S. F. (2002). Tourism in National Parks and Protected Areas: Planning and Management. Wallingford: CABI. http://dx.doi.org/10.1079/9780851995892.0000

Ealine, R. (1984). Satisfaction of tourists in private parks and recreation in New York. Dissertation Abstracts International, 44(10), 1120-1128.

Electricity Generating Authority of Thailand. (2010). Utility dams of the Electricity Generating Authority of Thailand [in Thai] Bangkok: Kong Palit Seusarn.

Empan, D. (2001). Satisfaction and behavior of tourists around Ubol Ratana Dam, Nam Pong District, Khon Kaen Province [in Thai]. Bangkok: Kasetsart University Press.

Hendee, J. C., et al. (1968). Wilderness users in the Pacific Northwest: Their characteristics, values and management preferences. Washington, D.C.: Pacific Northwest Forest and Range Experiment Station.

Hijaroen, W. (2003). Home-stay tourism management for conservation of the surrounding environment: A case study of Koh Yao Noi community, Phan-nga Province [in Thai]. Unpublished PhD thesis. Thaksin University, Songkhla.

Jaemulidrat, S. (1999). Ecotourism: opportunities and limitations of development - a case study of Koh Tao-Nang Yuan, Pha-Ngan District, Surat Thani Province [in Thai]. Unpublished PhD thesis. Mahidol University, Bangkok.

Jamrunsiri, A. (2003). Tourism and economic, social and cultural change: A case study of Nongbua Sub-district, Puruea District, Loei Province [in Thai]. Unpublished PhD Thesis. Loei Rajabhat University, Loei.

Jansen, H. (2010). The logic of qualitative survey research and its position in the field of social research methods. Forum: Qualitative social research, 11(2).

Jantawee, Y. (2005). Ecotourism management in mountain communities: A case study of the royal demonstration stations and inheritance of agriculture, forests and surrounding environment [in Thai]. Chiang Mai: Chiang Mai University Press.

Jitruangnan, A. (2003). Tourism and changes to the lifestyle of Lamnamwa community, Nan Province [in Thai]. Chiang Mai: Chiang Mai University Press.

Kanjanakit, S. (2001). Recreation and the tourism industry [in Thai]. Bangkok: Chulalongkorn University Press. 
Kreubun, P. (2002). Culture and the surrounding environment for developing cultural tourism in the Ngiw Neua village community, Ban Sang Sub-district, Mueang District, Payao Province [in Thai]. Chiang Mai: Chiang Mai University Press.

Lai, P. -O. \& Nepal, S. K. (2006). Local perspectives of ecotourism development in Tawushan nature reserve, Taiwan. Tourism Management, 27, 1117-1129. http://dx.doi.org/10.1016/j.tourman.2005.11.010

Larsen, R. K., Calgaro, E., \& Thomalla, F. (2011). Governing resilience building in Thailand's tourism-dependent coastal communities: Conceptualising stakeholder agency in social-ecological systems. Global Environmental Change, 21(2), 481-491. http://dx.doi.org/10.1016/j.gloenvcha.2010.12.009

Laverack, G., \& Thangphet, S. (2007). Building community capacity for locally managed ecotourism in Northern Thailand. Community Development Journal, 44(2), 172-185. http://dx.doi.org/10.1093/cdj /bsm058

Laws, E., Richins, H., \& Agrusa, J. (Eds.). (2011). Tourist destination governance: Practice, theory and issues. Wallingford: CABI. http://dx.doi.org/10.1079/9781845937942.0000

Leusittisak, W. (2004). Community participation in management of the surrounding environment from tourism activities: A case study of Wiang Kum Kam Ancient City, Saraphi District, Chiang Mai Province [in Thai]. Chiang Mai: Chiang Mai University Press.

Ministry of Tourism and Sports. (2010). The National Tourism Development Plan 2011-2016 [in Thai]. Bangkok: The War Veterans' Organization Printing Office.

Nantee, N. (2001). The development of cultural tourist attractions: A case study of Wat Pra Bat Huay Dom community, Peuli District, Lamphun Province [in Thai]. Chiang Mai: Chiang Mai University Press.

Office of the National Economic and Social Development Board. (2011). The Eleventh National Economic and Social Development Plan (2012-2016) [PDF]. Retrieved from http://eng.nesdb.go.th/Portals/0/news /plan/eng/THE\%20ELEVENTH\%20NATIONAL\%20ECONOMIC\%20AND\%20SOCIAL\%20DEVELOP MENT\%20PLAN\%282012-2016\%29.pdf

Pipattanayotapong, P. (2004). Management of home-stay accommodation for ecotourism: A case study of the Phu Thai culture village at Ban Khok Gong, Kuchinarai District, Kalasin Province [in Thai]. Unpublished $\mathrm{PhD}$ thesis. Chulalongkorn University, Bangkok.

Preissing, J. (2006). Community economic development strategic planning for rural communities: A case study of successful programs. Minneapolis, MN: Proquest.

Srisuwan, W. (2009). Cultural tourism management model through the participation of communities along the Tapi River [in Thai]. Unpublished $\mathrm{PhD}$ thesis. Mahasarakham University, Mahasarakham.

Stem, C.J. (2002). The role of local development in protected area management: a comparative case study of ecotourism in Costa Rica. Dissertation Abstracts International, 62(7), 3009-B.

Sukliang, P. (2002). Development of cultural tourist attractions: a case study of Huay Bong Palad Village, Wiang Ba Bao District, Chiang Rai Province [in Thai]. Chiang Mai: Chiang Mai University Press.

Swarbrooke, J. (2002). Development and management of visitor attractions. London: Taylor \& Francis.

Wasee, B. (2007). Management of the knowledge process to realize human potential, freedom and happiness [in Thai]. Bangkok: Green-Banyayan.

Wongduy, B. (2003). Management of natural resources and the surrounding environment in communities with home-stay programs: A case study of Mae Kampong King Village, Wiengmae-on District, Chiang Mai Province [in Thai]. Chiang Mai: Chiang Mai University Press.

Yotbakorn, N. (2004). Management of tourism companies that has an effect on the satisfaction of tourists: A case study of Pra Nakhon Si Ayutthaya [in Thai]. Unpublished PhD thesis. Pra Nakhon Si Ayutthaya Rajabhat University, Pra Nakhon Si Ayutthaya.

Yuyendee, N. (2003). Factors related to the preferences of home-stay activity participation among domestic Thai tourists [in Thai]. Unpublished PhD thesis. Kasetsart University, Bangkok. 


\section{Copyrights}

Copyright for this article is retained by the author(s), with first publication rights granted to the journal.

This is an open-access article distributed under the terms and conditions of the Creative Commons Attribution license (http://creativecommons.org/licenses/by/3.0/). 